\title{
Polarization(s) in Labour Markets
}

Introduction

Bruno Ducoudré and Véronique Simonnet

\section{(2) OpenEdition \\ Journals}

Electronic version

URL: http://journals.openedition.org/travailemploi/8909

DOI: 10.4000/travailemploi.8909

ISSN: 1775-416X

\section{Publisher}

DARES - Ministère du Travail

\section{Printed version}

Date of publication: 1 January 2019

Number of pages: 7-12

ISSN: 0224-4365

\section{Electronic reference}

Bruno Ducoudré and Véronique Simonnet, «Polarization(s) in Labour Markets », Travail et Emploi [Online], 157 | 2019, Online since 01 January 2019, connection on 10 December 2020. URL : http:// journals.openedition.org/travailemploi/8909; DOI : https://doi.org/10.4000/travailemploi.8909 


\title{
Introduction
}

\section{Polarization(s) in Labour Markets}

\author{
Bruno Ducoudré, Véronique Simonnet ${ }^{* *}$
}

$\mathrm{O}$ ver the last two decades, researchers have paid a lot of attention to polarization in labour markets, that is to say the rise of high- and low-wage jobs relative to middle-wage jobs. The international conference on "Polarization(s) in Labour Markets", organised by the Directorate for Research, Studies and Statistics (DARES, French Ministry of Labour) and the International Labour Organization (ILO), took place in Paris on June 19, 2018. The conference attempted to provide answers to a new set of questions on this subject: are there structural causes, other than technological change and the emergence of information and communication technologies (ICT), for the development of polarization? What about the reallocation of jobs in Europe and the United States when labour market institutions (minimum wage, taxation, etc.) pursue different objectives? How have routine activities declined? Who are the employees most affected by this decline and what are the consequences for them? Finally, what roles do international trade and firms play in the development of polarization and its geography?

Following this conference, the Editorial Board of Travail et Emploi has proposed to some of the participants to write an original paper bringing together the results of several of their most recent works, already published or in the course of publication. This issue therefore highlights recent research in economics on the subject of job polarization. First, it places the polarization phenomenon in the set of changes that labour markets have undergone since the 1950s. It then discusses the firms' transformations and workers' professional transitions in connection with the development of new technologies and international trade. This issue aims to take stock of the remaining issues that call for future developments in research on polarization.

\footnotetext{
* Observatoire français des conjonctures économiques (OFCE), Sciences Po ; bruno.ducoudre@ ofce.sciences-po.fr. ** Direction de l'animation de la recherche, des études et des statistiques (DARES), Mission animation de la recherche (MAR); veronique.simonnet@travail.gouv.fr.
} 


\section{What is Polarization of the Labour Market?}

At the beginning of the 2000s, researchers shed light on the phenomenon of polarization: the relative growth of wages and employment of high-wage occupations in the 1980s and 1990s and the relative growth of wages and employment of low-wage occupations compared to middle-wage occupations in the 1990s and the first decade of 2000 (AUTOR, DORN, 2013; AUTOR et al., 2006). This polarization is largely explained by the automation of routine tasks that disappear in favor of non-routine manual or cognitive tasks.

The study of the phenomenon originates from quantitative and case-study evidence that document a striking correlation between the adoption of computer-based technologies and the increased use of college-educated labour (this correlation is frequently interpreted as skill biased technological change). AUTOR et al. (2003) show that the rapid adoption of computer technologies, spurred by sharp real price decline, leads to changes in the tasks performed by workers and, ultimately, in the demand for human skills. Computer capital substitutes workers in performing cognitive and manual tasks that can be accomplished according to an explicit set of rules -called "routine tasks". Conversely, it complements workers in performing tasks that require flexibility, creativity, problem-solving skills, and complex communication activitiescalled "non-routine tasks." As the price of computer capital falls, these two mechanisms (substitution and complementarity) raise relative demand for workers who have a comparative advantage in non-routine tasks, typically the more educated workers.

But AUTOR et al. (2003) show that the changing composition of job tasks spurred by technological change affects almost all occupations and educational levels. It thus appears before the rise in the general level of education and accounts for $60 \%$ of the estimated relative demand growth favouring college labour between 1970 and 1998 in the United States. Their model predicts also that industries that are initially intensive in labour inputs will invest the most in computers and new technologies as their prices decline, thus triggering a considerable reduction in routine activities and an increase in non-routine activities. These industries would reduce labour demand for routine tasks, for which computer capital substitutes, and increase labour demand for non-routine tasks, which computer capital complements.

Goos and MANNING (2007) further specify that routine tasks that require precision and can be performed by machines (such as some accounting tasks, for example), are not necessarily those requiring the lowest skill levels. Conversely, some non-routine manual tasks that essentially involve coordination (such as shelving, or tasks performed in service occupations involving assisting or caring for others) require very little qualification. As a result, automation leads to increased demand for well-paying skilled jobs that typically require non-routine cognitive skills and increased demand for low-skilled, low-wage jobs that typically require non-routine 
manual skills. ${ }^{1}$ In contrast, there is less demand for "intermediate" jobs that require routine manual and cognitive skills. This process leads to job polarization and by extension to wages polarization. If the most skilled workers generally perform nonroutine cognitive tasks and the least skilled workers perform manual non-routine tasks, employment polarization corresponds to an increase in jobs at both the top and the bottom of the wage distribution. The reduction of routine tasks, whether cognitive or manual, leads to a reduction in the share of jobs located in the middle of the distribution. One can thus observe polarization by looking at the evolution of employment per salary centile. By ranking and having a close look at the lowest paid occupations, the middle and the highest paid occupations, Goos et al. (2009, 2014) confirm the polarization of employment in all European countries over the period 1993-2010.

Finally, AUTOR and DORN (2013) suggest that the fall in the price of new technologies that drives down the wage paid to routine tasks leads some low-skilled workers to switch to service occupations that are difficult to automate because "they rely heavily on dexterity, flexible interpersonal communication, and direct physical proximity" (p. 1590). ${ }^{2}$ As in these sectors there is currently no substitutability between goods and services, the substitution of routine human tasks by machines in the production of goods can allow a growth of wages and employment in low-skilled service occupations. ${ }^{3}$

\section{Sources and Consequences of Polarization}

The polarization of labour markets has raised a series of questions relating both to its origins, to the mechanisms at work and their consequences on occupational patterns and the wage distribution, to individual workers' occupational mobility patterns and wage trajectories and to the differentiated effects among social groups. In the first article of this issue of Travail et Emploi, Alan Manning addresses these questions, stating that polarization is a structural phenomenon prior to the diffusion of ICT. Zsófia Bárány and Christian Siegel demonstrate this point, explaining that the manufacturing share of employment began to decline as early as the 1960s, while services employment increased, and that wage differentials between services and manufacturing with equal skills increased. Since routine jobs are largely concentrated

\footnotetext{
1. Non-routine manual tasks need "eye-hand-foot" coordination. Non-routine cognitive tasks include "control, planning and direction" tasks, which correspond to managerial and interactive tasks, and/or the need for mathematical and formal reasoning. Routine tasks are identified by the possibility to set "limits, tolerances and standards" and by "finger dexterity" practice (Goos, MANNING, 2007).

2. Such as services related to transportation, accommodation and food, personal care, building and grounds cleaning, housekeeping, delivery and security services.

3. This requires a strong elasticity of substitution between routine tasks and new technologies, on the one hand, and a low elasticity of substitution between goods and services, on the other hand. The decline in the price of new technologies then benefits the development of non-routine-manual-skills intensive services.
} 
in manufacturing and located in the middle of the wage distribution, these reallocations have led to job polarization in the United States. This structural change has led to a reallocation of jobs between sectors and within sectors.

While the share of jobs requiring cognitive skills has grown across all sectors and the share of routine jobs has declined, half of the increase in manual employment has been due to the reallocation of employment between sectors -these employment reallocations evolving in accordance with the rate of diffusion of new technologies within the sectors and occupations. Zsófia Bárány and Christian Siegel show that the diffusion of new technologies within some occupations, and within some occupations in some sectors, is much faster than in any sector in general.

Alan Manning also points out the links between polarization and inequality, and the fact that structural changes in labour markets generate "winners" and "losers". Polarization does not manifest itself so much as a massive rise in wage inequalities between occupations -the supply of work by occupation is very elastic to relative wages between jobs- but rather as differentiated impacts among individuals and social groups. Guido Matias Cortes shows that in the United States, polarization has resulted in a decline in manufacturing skilled workers' jobs and middle-level administrative jobs. Thus, routine manual occupations have declined with the decrease in the proportion of men aged 20 to 50 without a diploma or with little education in the population, but even more so because of the decrease in men's probability of working in routine manual occupations. Two thirds of the decline in routine cognitive activities come from the decline in the probability of women aged 20 to 50 with high school diplomas or some post-secondary education of working in routine cognitive activities. Both these declines in the probability of working in routine activities have resulted in a slight increase in nonroutine manual employment but above all in a strong growth in non-employment, which could partly explain the decline in men's employment rate observed in the United States during this period. Women have experienced fewer transitions to non-employment than men but have not switched to non-routine cognitive occupations either. Guido Matias Cortes also shows that the wage growth of men remaining in routine occupations is much lower than that of men who have switched from routine to non-routine occupations, even though those non-routine occupations are low-skilled manual jobs.

Polarization is a global phenomenon since it affects all countries, regardless of their income level, and since it grows in parallel with globalization, the two phenomena appearing to feed on one another. Fredrik Heyman and Fredrik Sjöholm highlight the links observed in Sweden between labour market polarization and the degree of firms' exposure to international competition. On the one hand, they show that multinational firms and exporting firms employ more highly-skilled workers than do local firms; on the other hand, global engagement impacts firm organization and the occupational structure of firms. Firms with a high initial level of routine jobs increase their share of high- and low-skilled jobs at the expense of routine, middle-skilled jobs. Technological change leading to a decline of routine jobs and to job polarization can improve firms' competitiveness and support the development of their international activities. Increased 
export shares skew the labour mix toward high-skilled occupations. Offshoring would help to increase both high-skilled and low-skilled occupations.

Finally, what is the overall impact of polarization on economies? Does it mean a rise or a fall in wages in the long term? Alan Manning provides answers by showing how technology can benefit workers on average over the long term, through a rise in average wages. This occurs when the capital stock varies in the long term, while the quantity of labour input available is limited, and the relative price of investment decreases in the long term. Under these conditions, productivity gains must benefit the compensation of employees as a whole, which would generate additional demand for goods and services that create jobs. This does not mean that there are only winners, since significant redistributive effects can occur simultaneously. With these results, Alan Manning invites us to think about the policies to implement so that gains from the diffusion of new technologies benefit the largest number as well as the instruments that can be mobilised: minimum wages, training policies, redistributive taxation.

This issue of Travail et Emploi does not claim to be exhaustive, ${ }^{4}$ since it does not deal with the role of labour market institutions in the development of polarization. A minimum wage can thus influence the evolution of the occupational pattern, and offset wage inequalities if its level is high enough. Training systems for people working in occupations affected by automation are also ways to support their career transitions. The links (or lack of links) between labour markets polarization in high-income countries and offshoring in low-income countries have to be clarified, especially because polarization in labour markets in low-income countries is not clearly established. According to MALONEY, Molina (2016), different reasons can explain this result. Let's give three of them: compared to developed countries, the share of routine occupations is often less important in developing countries since employment in the primary sector is still important; routine occupations in developing countries can partly benefit from offshoring; investment in new technologies may also be lower. The phenomenon of polarization also seems to have a spatial dimension, since it can impact the structure of employment and wages of local labour markets differently. AUTOR (2019) shows how technological changes have affected low-educated urban workers by reducing their advantage in working in metropolitan areas because routine occupations have been reduced in these areas. Finally, recent developments in artificial intelligence, and its potential to replace workers to perform some highly-skilled tasks (for example the diagnosis of certain diseases) raise the question of its complementarity or substitutability with high-skilled workers, which could deeply modify the process of polarization (FRANK et al., 2019). However, the effects of artificial intelligence development on productivity and employment may be slow to spread; both because the accumulation of capital stock based on this technology would take time to have macroeconomic effects, but also because its diffusion would require additional investments (BRYNJOLFSSON et al., 2017). All these questions open up fundamental research perspectives for the years to come.

4. See Delautre, Simonnet, 2018 for a more complete state of the works on polarization. 


\section{REFERENCES}

Autor, D. (2019). Work of the Past, Work of the Future. NBER Working Paper, no 25588.

Autor, D. H., Dorn, D. (2013). "The Growth of Low-Skill Service Jobs and the Polarization of the US Labor Market.” American Economic Review, 103(5), 1553-1597. https://doi. org/10.1257/aer.103.5.1553.

Autor, D. H., Katz, L. F., Kearney, M. S. (2006). "The Polarization of the U.S. Labor Market.” American Economic Review, 96(2), 189-194. https://doi.org/10.1257/000282806777212620.

Autor, D. H., Levy, F., Murnane, R. J. (2003). “The Skill Content of Recent Technological Change: An Empirical Exploration.” The Quarterly Journal of Economics, 118(4), 1279-1333. https://doi.org/10.1162/003355303322552801.

Brynjolfsson, E., Rock, D., Syverson, C. (2017). Artificial Intelligence and the Modern Productivity Paradox: A Clash of Expectations and Statistics. NBER Working Paper, no 24001.

Delautre, G., Simonnet, V. (2018). « Polarisation sur les marchés du travail : quelles réalités ? Les Notes de la MAR, 2. Paris : Direction de l'animation de la recherche, des études et des statistiques (DARES).

Frank, M. R., Autor, D., Bessen, J. E., Brynjolfsson, E., Cebrian, M., Deming, D. J., Feldman, M., Groh, M., Lobo, J., Moro, E., Wang, D., Youn, H., Rahwan, I. (2019). “Toward Understanding the Impact of Artificial Intelligence on Labor." Proceedings of the National Academy of Sciences, 116(14), 6531-6539. https://doi.org/10.1073/pnas.1900949116.

Goos, M., Manning, A. (2007). "Lousy and Lovely Jobs: The Rising Polarization of Work in Britain." The Review of Economics and Statistics, 89(1), 118-133. https://doi.org/10.1162/ rest.89.1.118.

Goos, M., Manning, A., Salomons, A. (2009). "Job Polarization in Europe." American Economic Review, 99(2), 58-63. http://doi.org/10.1257/aer.99.2.58.

Goos, M., Manning, A., SAlomons, A. (2014). "Explaining Job Polarization: Routine-Biased Technological Change and Offshoring." American Economic Review, 104(8), 2509-2526. https://doi.org/10.1257/aer.104.8.2509.

Maloney, W. F., Molina, C. A. (2016). Are Automation and Trade Polarizing Developing Country Labor Markets, Too? Policy Research Working Paper, no WPS 7922. Washington, D. C.: World Bank Group. 